\section{Will SPAR be useful in the usual patients with scleroderma?}

We read with great interest the simplified predictive score 'SPAR model' by Wu et al. ${ }^{1}$ A simplified predictive score which can predict 'fast progressors' can be used to target and selectively recruit such patients for drug trials and finally lead to improvement in outcomes in the future. However, certain aspects require clarification.

First, the external validity of the patients recruited is unclear. Although early interstitial lung disease (ILD) as defined in the study $(<20 \%$ CT involvement) would be common, approximately half of the patients of this study could be having forced vital capacity (FVC) $>100 \%$ (assuming normality). The latter would be a subgroup which would be uncommon. More interestingly, these patients have never been recruited for interventional studies looking at drugs on ILD—both the scleroderma lung studies (refs ${ }^{2}$ and ${ }^{3}$ ) recruited patients with FVC $\leq 85 \%$; thus we have no idea whether they (FVC>100\%) respond to therapy. In the latter study (SLS2), only 30 out of 198 screened systemic sclerosis were excluded due to pulmonary function test, which could be higher or lower FVC and diffusing capacity of the lung for carbon monoxide-. The authors may like to provide their cohort numbers and how many of them fulfilled the inclusion criteria.

Second, the authors found 'arthritis ever' to be significant after multivariate analysis, though a previous study did not show any association of arthritis and ILD progression. ${ }^{4}$ However, there is no comment on whether arthritis was persistent and erosive, and did it require treatment in their cohort? Was baseline presence of arthritis also significant? In a patient who comes for the first time, history of arthritis would not be available.

Third, the best multivariate predictive model in this study (model 3 (SpO2 $\leq 94 \%+$ arthritis ever)) has a sensitivity of only $44 \%$, thus more than half of the progressors would not be detected. Even in a 0-2 SPAR score, the most common score is 1 , and that would only identify one-third of progressors! ${ }^{1}$

Finally, the authors may like to provide any data on other variables expected to predict progression-baseline extent of ILD on CT (varying from $0 \%$ to 20\%), oesophageal diameter on high-resolution CT (as shown by other studies ${ }^{25}$ ) and nail fold capillaroscopy. The latter becomes important as low oxygen saturation after the 6 min walk test, when severe ILD and pulmonary artery hypertension (PAH) are excluded (as in this study), may reflect early microvasculature changes in pulmonary bed, which as expected to be generalised and would be reflected in the nail bed capillaries also.

\section{Arghya Chattopadhyay, Varun Dhir, Shefali Sharma, Aman Sharma,} Sanjay Jain

Internal Medicine, Clinical Immunology and Rheumatology Services, Chandigarh, India

Correspondence to DrVarun Dhir, Clinical Immunology and Rheumatology Services, Chandigarh 160012, India; varundhir@gmail.com

Funding The authors have not declared a specific grant for this research from any funding agency in the public, commercial or not-for-profit sectors.

Competing interests None declared.

Patient consent Not required.

Provenance and peer review Not commissioned; internally peer reviewed.

(c) Author(s) (or their employer(s)) 2019. No commercial re-use. See rights and permissions. Published by BMJ.

\section{Check for updates}

To cite Chattopadhyay A, Dhir V, Sharma S, et al. Ann Rheum Dis 2019;78:e125.

Received 9 August 2018

Accepted 12 August 2018

Published Online First 7 September 2018

\section{Linked}

http://dx.doi.org/10.1136/annrheumdis-2018-214270

Ann Rheum Dis 2019;78:e125. doi:10.1136/annrheumdis-2018-214256

\section{REFERENCES}

1 Wu W, Jordan S, Becker MO, et al. Prediction of progression of interstitial lung disease in patients with systemic sclerosis: the SPAR model. Ann Rheum Dis. 2018;77:1326-32.

2 Tashkin DP, Elashoff R, Clements PJ, et al. Cyclophosphamide versus placebo in scleroderma lung disease. N Engl J Med Overseas Ed 2006;354:2655-66.

3 Tashkin DP, Roth MD, et al. Sclerodema Lung Study II Investigators. Mycophenolate mofetil versus oral cyclophosphamide in scleroderma-related interstitial lung disease (SLS II): a randomised controlled, double-blind, parallel group trial. Lancet Respir Med 2016:4:708-19.

4 Avouac J, Walker UA, Hachulla E, et al. Joint and tendon involvement predict disease progression in systemic sclerosis: a EUSTAR prospective study. Ann Rheum Dis 2016;75:103-9.

5 Richardson C, Agrawal R, LeeJ AO. Dilated esophagus is an independent risk factor for interstitial lung disease in SSc. Abstract number: 729 Meeting: 2014 ACR/ARHP Annual Meeting. 